\title{
Overcoming The Socio-Economic Consequences Of Military Conflict in Ukraine And The Impact Investment Of Post-Conflict Recovery Of Anti-Terrorist Operation
}

https://doi.org/10.21272/sec.4(3).132-142.2020

Yulia Yelnikova, ORCID: https://orcid.org/0000-0002-8478-4716

PhD, Senior Research Fellow, Department of Accounting and Taxation, Sumy State University, Ukraine

Aleksandra Kuzior, ORCID: http://orcid.org/0000-0001-9764-5320

Hab. Dr., Professor, Faculty of Organization and Management, Silesian University of Technology, Poland

\begin{abstract}
The article analyzes the socio-economic consequences of the armed conflict for the economic development of the ATO regions. The key problems related to the temporarily occupied territories were identified, the directions of their solution and the role that impact investment can play in this were specified. A dynamic analysis of indicators of socio-economic development of Ukrainian economy as a whole and in the regional context for the period from 2012 to 2019 was conducted. It is determined that the loss of territorial control has led to a significant deterioration of the economy in Ukraine; the assessment of losses of economic potential at the anti-terrorist operation zone was carried out. The social component of this issue is analyzed separately, namely, how the conflict affected the population, the loss of human capital, in particular due to mass displacement. These include human losses, forced displacement, destruction of physical infrastructure, disruption of so-called soft economic infrastructure (for example, existing links between sellers and consumers). Given the scale of losses and consequences, we can talk about a wide range of areas for impact investment, related to economic recovery in post-conflict regions. The article presents a list of steps to restore the occupied territories, which can be translated into the plane of solving socio-economic problems, as well as an assessment of the overall needs for the restoration of government-controlled areas of the ATO. This allowed us to conclude that the restoration of infrastructure is one of the most promising areas for attracting investment and implementing impact investment. However, a study of this area for investment revealed that not all areas will be cost-effective and attractive to investors. Therefore, the direction of impact investments immediately after the political settlement of the conflict in Donbass in infrastructure should be expected only in the field of telecommunications. Other sectors will receive private investment only after a few years of stability, so only public financial support and public investment policy should be considered a key source of funding.
\end{abstract}

Keywords: socio-economic consequences, recovery, military conflict, impact investment, loss assessment, development.

JEL Classification: F50, F51, H12, H56, O52.

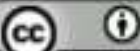

Cite as: Yelnikova, Yu., Kuzior, A. (2020). Overcoming The Socio-Economic Consequences Of Military Conflict in Ukraine And The Impact Investment Of Post-Conflict Recovery Of Anti-Terrorist Operation. SocioEconomic Challenges, 4(3), 132-142. https://doi.org/10.21272/sec.4(3).132-142.2020.

(C) The Authors, 2020. This article is published with open access at Sumy State University.

\section{Introduction}

The situation around the temporarily occupied territories of Donetsk and Luhansk oblasts and the Autonomous Republic of Crimea remains difficult. The conflict resolution is in the realm of politics and military operations. The consequences and timing of their return are uncertain. The loss of territory and military conflict have affected many economic indicators, leading to new problems and challenges that the country has not dealt with before. The most important are the resettlement of citizens of Ukraine from the temporarily occupied territories, promoting their reintegration into socio-economic life, reorientation of export-import activities, restoration of 
economic development, infrastructure, social sphere and more. Thus, the aim of the article is to analyze the consequences of the military conflict for the country and the need for post-conflict reconstruction.

\section{Literature review}

This topic has been studied by both foreign and domestic scientists. Thus, in the works of Paul Collier, Bello Walden, Cedric de Coning, Tim Murithi, the main goal is to find rational approaches and methods to overcome the consequences of economic nature for the economy of the country. Also their work on peacebuilding in postconflict regions is important, which highlights the main problems and ways to solve them in different scenarios of sustainable development.

It should be noted that domestic scientists in the study of the recovery of the post-conflict economy are mainly divided into three areas. The first is a study in the field of banking and insurance. Such scientists include M.M. Alexandrova (2011), O.O. Reznikov (2001), O.V. Kozmenko (1998), L.S. Koval (1998), A.V. Koldovskyi (2013), I.I. Strelchenko (2009), K. Pajak et al. (2016). The second direction is taxation, budget and investment, the supporters of which are M.O. Matukhno (2015), I.G. Lukyanenko (2005), A.O. Nikitishin (2009), R.Yu. Paslavska (2014). Representatives of the third direction, namely accounting and control at all state at the commercial levels of development of the country are N.G. Vyhovska (2010), I.K. Drozd (2006), V.V. Evdokymov (2011), V. Lyashenko \& I. Pidorycheva (2019), L.M. Kindratska (2002), A. Kuzior \& P. Kuzior (2020), A. Kwilinski (2018), A. Kwilinski et al. (2019a; 2019b), A. Kuzior \& J. Zozulak (2019). V. Kondratenko et al. (2020), A. Kwilinski \& A. Kuzior (2020), L. Mikhnevych et al. (2020). Given the large number of studies that reveal the essence of post-conflict recovery, there is a need to analyze the current state of the economy and the consequences of military conflict in terms of national development.

\section{Results}

When studying the state of the national economy and changes in economic indicators, we should first pay attention to the changes that have taken place in recent years in Ukraine, identify key issues related to the temporarily occupied territories, specify their solutions and the role that can play an impact investing in it.

Let's analyze the dynamics of macroeconomic indicators for the last 8 years in 2012-2019 (see Table 1). If you look at the dynamics of GDP in nominal terms, the situation looks quite optimistic. The smallest increase is observed in 2013-2014 and it is about 4\% and more than 20\% in subsequent years, except for 2019, when it reached $11.6 \%$. For a more objective assessment, the index of the physical volume of GDP to the previous year is suitable, according to which we can see the real consequences of the military conflict. In 2014, we managed to reach only $93.4 \%$ of the previous year's volume, and in 2015 this figure was $90.2 \%$. In the following years, although it increased (the figure was in the range of 102.4-103.4\% in 2016-2019), but the economy did not recover to the level of 2012-2013. These processes are accompanied by significant levels of the consumer price index for goods and services 124.9 and 143.3 in 2014 and 2015, respectively. In the future, its values remained high with relative normalization only at the end of 2019 (104.1). The level of the unemployed population also increased from $7.2 \%$ in 2013 to $8.8-9.5 \%$ in $2014-2018$, i.e. the difference ranges from $1 / 4$ to $1 / 3$ of the figure in 2013. Revenues and expenditures of the consolidated budget of Ukraine change sharply after 2014. A onetime increase of $43 \%$ and $30 \%$, respectively, next year with their further growth at a slightly slower pace due to high inflation and the need to finance defense spending.

Table 1. Indicators of economic development of Ukraine in 2012-2019

\begin{tabular}{|l|c|c|c|c|c|c|c|c|}
\hline Indicator & $\mathbf{2 0 1 2}$ & $\mathbf{2 0 1 3}$ & $\mathbf{2 0 1 4}^{\mathbf{1}}$ & $\mathbf{2 0 1 5}^{\mathbf{1}}$ & $\mathbf{2 0 1 6}^{\mathbf{1}}$ & $\mathbf{2 0 1 7}^{\mathbf{1}}$ & $\mathbf{2 0 1 8}^{\mathbf{1}}$ & $\mathbf{2 0 1 9}^{\mathbf{1}}$ \\
\hline Gross domestic product, UAH million & 1459096 & 1522657 & 1586915 & 1988544 & 2385367 & 2983882 & 3560596 & 3974564 \\
\hline GDP growth rate, \% & 12.2 & 4.4 & 4.2 & 25.3 & 20.0 & 25.1 & 19.3 & 11.6 \\
\hline Index of physical volume of GDP to the previous year, \% & 100.2 & 100.0 & 93.4 & 90.2 & 102.4 & 102.5 & 103.4 & 103.2 \\
\hline Consumer price index for goods and services, $\%$ & 99.8 & 100.5 & 124.9 & 143.3 & 112.4 & 113.7 & 109.8 & 104.1 \\
\hline Unemployment rate, $\%$ & 7.5 & 7.2 & 9.3 & 9.1 & 9.3 & 9.5 & 8.8 & 8.2 \\
\hline Capital investments, UAH million & 273256 & 249873 & 219420 & 273116 & 359216 & 448462 & 578726 & 623979 \\
\hline Consolidated budget revenues, UAH million & 445525 & 442789 & 456067 & 652031 & 782859 & 1016970 & 1184291 & 1289849 \\
\hline Consolidated budget expenditures, UAH million & 492455 & 505844 & 523126 & 679871 & 835832 & 1056973 & 1250190 & 1372351 \\
\hline Consolidated budget deficit, UAH million & -46929 & -63055 & -67058 & -27840 & -52973 & -40004 & -65899 & -82501 \\
\hline in\% of GDP & 3.22 & 4.14 & 4.23 & 1.40 & 2.22 & 1.34 & $1.8 \%$ & 2.08 \\
\hline Volume of sold construction products, UAH million & 142948 & 131548 & 147344 & 133450 & 160647 & 215100 & 294543 & 364056 \\
\hline Retail trade turnover, UAH million & 812052 & 888773 & 901924 & 1031679 & 1175319 & 815344 & 930629 & 1094046 \\
\hline
\end{tabular}

Notes: ${ }^{1}$ Excluding the temporarily occupied territory of the Autonomous Republic of Crimea, the city of Sevastopol and part of the temporarily occupied territories in Donetsk and Luhansk oblasts. 
Table 2. Indicators of regional development of Ukraine in 2012-2019

\begin{tabular}{|c|c|c|c|c|c|c|c|c|}
\hline Indicator & 2012 & 2013 & $2014^{1}$ & $2015^{1}$ & $2016^{1}$ & $2017^{1}$ & $2018^{1}$ & $2019^{1}$ \\
\hline $\begin{array}{l}\text { Gross regional } \\
\text { product, UAH million, } \\
\text { including }\end{array}$ & 1459096 & 1522657 & 1586915 & 1988544 & 2385367 & 2983882 & 3560596 & 3974564 \\
\hline Donetsk oblast & 170775 & 164926 & 119983 & 115012 & 137500 & 166404 & 192256 & $\mathrm{n} / \mathrm{a}$ \\
\hline$\%$ of GDP & $11.7 \%$ & $10.8 \%$ & $7.6 \%$ & $5.8 \%$ & $5.8 \%$ & $5.6 \%$ & $5.4 \%$ & $\mathrm{n} / \mathrm{a}$ \\
\hline Luhansk oblast & 58767 & 55108 & 31393 & 23849 & 31356 & 30285 & 35206 & $\mathrm{n} / \mathrm{a}$ \\
\hline$\%$ of GDP & $4.0 \%$ & $3.6 \%$ & $2.0 \%$ & $1.2 \%$ & $1.3 \%$ & $1.0 \%$ & $1.0 \%$ & $\mathrm{n} / \mathrm{a}$ \\
\hline $\begin{array}{l}\text { Volume of sold } \\
\text { industrial products } \\
\text { (goods, services), } \\
\text { UAH million, incl. }\end{array}$ & 1367926 & 1322408 & 1428839 & 1776604 & 2158030 & 2625863 & 3045202 & 2938831 \\
\hline Donetsk oblast & 242229 & 220640 & 181385 & 190727 & 212098 & 266626 & 322988 & 283946 \\
\hline Luhansk oblast & 84460 & 72657 & 39401 & 23866 & 37698 & 24473 & 24136 & 21908 \\
\hline $\begin{array}{l}\text { gricultural products } \\
\text { (at constant prices in } \\
\text { 2016), UAH million, } \\
\text { incl. }\end{array}$ & 539991 & 613429 & 626925 & 596833 & 634433 & 620476 & 671294 & 680982 \\
\hline Donetsk oblast & 26154 & 27587 & 25679 & 16644 & 18006 & 18422 & 16662 & 20261 \\
\hline Luhansk oblast & 16116 & 16630 & 13282 & 10320 & 12299 & 11573 & 12628 & 14448 \\
\hline \multicolumn{9}{|c|}{ Regional volumes of foreign trade in goods, thousand dollars USA } \\
\hline Export & 68809811 & 63312022 & 53901689 & 38127150 & 36361711 & 43264736 & 47334987 & 50054606 \\
\hline Donetsk oblast & 14127179 & 12408183 & 8402968 & 3695324 & 3430784 & 4432600 & 4845441 & 4631583 \\
\hline Luhansk oblast & 4192709 & 3544015 & 1902640 & 257772 & 435727 & 233905 & 202921 & 152851 \\
\hline Import & 84658060 & 76963965 & 54428717 & 37516443 & 39249797 & 49607174 & 57187578 & 60800173 \\
\hline Donetsk oblast & 4168469 & 4053798 & 2122395 & 1202633 & 1110777 & 2033912 & 2247214 & 2224442 \\
\hline Luhansk oblast & 1989589 & 1849914 & 1017230 & 318426 & 357396 & 273152 & 285036 & 252961 \\
\hline $\begin{array}{l}\text { Number of active } \\
\text { enterprises }\end{array}$ & 622538 & 669993 & 631184 & 624769 & 605851 & 640545 & 666986 & 697282 \\
\hline Donetsk oblast & 46211 & 48580 & 47389 & 31820 & 31437 & 30738 & 30720 & 31481 \\
\hline Luhansk oblast & 20242 & 21797 & 21618 & 13891 & 14204 & 13805 & 14010 & 14347 \\
\hline
\end{tabular}

Notes: ${ }^{1}$ Excluding the temporarily occupied territory of the Autonomous Republic of Crimea, the city of Sevastopol and part of the temporarily occupied territories in Donetsk and Luhansk oblasts.

Table 3. The contribution of Donetsk and Luhansk oblasts in the main sectors of the economy, the share in the relevant indicator before the conflict and now

\begin{tabular}{|l|c|c|c|c|c|c|c|c|}
\hline \multirow{2}{*}{ Indicator } & \multicolumn{2}{|c|}{ Donetsk oblast } & \multicolumn{2}{c|}{ Luhansk oblast } & \multicolumn{3}{c|}{ Total } & \multicolumn{2}{c|}{ Change of indicator } \\
\cline { 2 - 8 } & 2013 & 2019 & 2013 & 2019 & 2013 & 2019 & 2013 & 2019 \\
\hline Workforce & $9.7 \%$ & $4.8 \%$ & $4.9 \%$ & $2.0 \%$ & $14.6 \%$ & $6.8 \%$ & $-7.9 \%$ & $-53.8 \%$ \\
\hline Number of employees in enterprises & $11.6 \%$ & $4.4 \%$ & $4.5 \%$ & $1.1 \%$ & $16.1 \%$ & $5.5 \%$ & $-10.6 \%$ & $-65.9 \%$ \\
\hline Incomes of the population & $10.7 \%$ & $5.3 \%$ & $4.6 \%$ & $1.8 \%$ & $15.4 \%$ & $7.1 \%$ & $-8.2 \%$ & $-53.6 \%$ \\
\hline Expenditures of the population & $9.8 \%$ & $3.5 \%$ & $4.3 \%$ & $1.3 \%$ & $14.0 \%$ & $4.8 \%$ & $-9.3 \%$ & $-65.9 \%$ \\
\hline Gross regional product & $10.8 \%$ & $3.6 \%$ & $5.4 \%$ & $1.0 \%$ & $16.2 \%$ & $4.6 \%$ & $-11.6 \%$ & $-71.6 \%$ \\
\hline $\begin{array}{l}\text { Volume of sold industrial products (goods, } \\
\text { services) }\end{array}$ & $16.7 \%$ & $9.7 \%$ & $5.5 \%$ & $0.7 \%$ & $22.2 \%$ & $10.4 \%$ & $-11.8 \%$ & $-53.1 \%$ \\
\hline Agricultural products & $4.5 \%$ & $3.0 \%$ & $2.7 \%$ & $2.1 \%$ & $7.2 \%$ & $5.1 \%$ & $-2.1 \%$ & $-29.3 \%$ \\
\hline The volume of construction work performed & $12.9 \%$ & $3.8 \%$ & $2.7 \%$ & $0.4 \%$ & $15.7 \%$ & $4.2 \%$ & $-11.4 \%$ & $-73.1 \%$ \\
\hline Capital investments & $11.2 \%$ & $4.9 \%$ & $4.6 \%$ & $0.5 \%$ & $15.7 \%$ & $5.4 \%$ & $-10.3 \%$ & $-65.4 \%$ \\
\hline Export & $19.60 \%$ & $9.25 \%$ & $5.60 \%$ & $0.31 \%$ & $25.2 \%$ & $9.6 \%$ & $-15.6 \%$ & $-62.1 \%$ \\
\hline Imports & $5.27 \%$ & $3.66 \%$ & $2.40 \%$ & $0.42 \%$ & $7.7 \%$ & $4.1 \%$ & $-3.6 \%$ & $-46.9 \%$ \\
\hline Number of active enterprises & $7.3 \%$ & $4.5 \%$ & $3.3 \%$ & $2.1 \%$ & $10.5 \%$ & $6.6 \%$ & $-3.9 \%$ & $-37.4 \%$ \\
\hline
\end{tabular}

Notes: Data for 2019 are given without taking into account the temporarily occupied territory of the Autonomous Republic of Crimea, the city of Sevastopol and part of the temporarily occupied territories in Donetsk and Luhansk oblasts.

The reaction to the aggravation of the situation around the military conflict is the volume of sold construction products, which in 2015 decreased by $9.5 \%$ compared to the previous year, although in the future we see its significant growth at a rate of $20-37 \%$.

Retail trade turnover grew by about $10 \%$ until 2016, after which we see its decline by almost a third, which to some extent goes beyond the general trends of other economic indicators. However, in our opinion, the reasons for the changes are similar only with a certain time lag.

Thus, the conclusion is obvious:the loss of territorial control has led to a significant deterioration of Ukrainian economy. The concretization of the consequences around the temporarily occupied territories of Donetsk and 
Luhansk oblasts should be accompanied by an additional analysis of individual indicators of this region (see Table 2). This allows you to get an approximate estimate of the loss of economic potential in the region.

First, a key indicator of significant losses is the reduction in gross regional product. As noted earlier, Ukrainian GDP grows in nominal terms, including due to high inflation. At the same time, we observe a decrease in the regional product for three years in Donetsk and Luhansk oblasts in a row - 2013-15. And when in 2013 this decrease was insignificant $3.4 \%$ in Donetsk and $6.2 \%$ in Luhansk oblasts, already in the following years, volumes fell by $27.3 \%$ and $43.0 \%$ in 2014 and by $4.1 \%$ and $24.0 \%$, respectively. As a result, the share of Donetsk oblast in the GDP of Ukraine decreases from 11-12\% to 5.5\%, i.e. 2 times. Luhansk oblast has lost even more. The share is reduced by $4 \%$ to only $1 \%$.

There is a decline in sales of industrial products. The gross volume of the indicator grows in Ukraine, while it decreases in the occupied regions. In 2013-14, the decrease in volumes in Donetsk oblast was 9\% and 18\%, respectively, after which there was a recovery. But the share of the region in total sales falls from $18 \%$ to $9 \%$. At the same time, Luhansk oblast loses even more: $14 \%$ and $46 \%$ of the indicator in the respective years, but the decline continues in the future (except 2016): $39.4 \%$ in 2015, 35.1\% in 2017. As a result, the share of the region in this indicator decreases from $6 \%$ to $0.7 \%$, more than 8 times.

The reasons are obvious: a significant number of industrial enterprises remained in the occupied territories. In particular, in Luhansk oblast budget-generating enterprises of the metallurgical industry were PJSC "Alchevsk Metallurgical Plant”, PJSC "Stakhanov Ferroalloy Plant”, PJSC “Lugansk Pipe Plant”, Lutugino State Research and Production Rolling Mill, LLC "Metals and Polymers", machine-building enterprises PJSC "Stakhanov Carriage Plant", PJSC "Luganskteplovoz", PJSC "NVC "Transmash", TDV "Popasnyansky Car Repair Plant", etc. In Donetsk oblast, the Donetsk, Yenakiyevo and Makiivka metallurgical plants, the Donetsk Electrometallurgical Plant, the Yenakiyevo Coke Plant, and the Makiivka Coke Plant should be distinguished.

In 2013, the mines in Donetsk and Luhansk oblasts provided $76 \%$ of coal production in Ukraine. Already in 2014, Ukraine lost control over the main coal mining areas of both regions. The Ministry of Energy and Coal of Ukraine states that there are 97 mines left in the occupied part of the region (55 in Donetsk oblast, 42 in Luhansk oblast).

Agricultural products are not the main contribution of the occupied region to its total volume in the country. In 2012, both oblasts accounted for 7.8\%. After 2015, it exceeded 5\% only in 2019. A significant decline was recorded again in 2015: 35.2\% in Donetsk oblast and 22.3\% in Luhansk oblast.

The analysis of regional volumes of foreign trade shows that both regions rapidly lose their entire export orientation. Back in 2012, Donetsk region accounted for more than 20\%, and Luhansk more than 6\% of export revenues from foreign trade in goods, and three years later we see a complete collapse: less than $10 \%$ in Donetsk and less than $1 \%$ in Lugansk oblast. The value of imported products is much lower, but even here the share of Donetsk oblast falls from 5\% to less than $4 \%$, and Luhansk - from $2.5 \%$ to $0.5 \%$.

The number of active enterprises in both regions falls by a third when comparing 2015 with 2014. After that, a significant increase in newly created businesses is not observed, while in the country as a whole the number gradually increases.

Separately, we will analyze how the conflict affected the population. Thus, according to the Office of the United Nations High Commissioner for Human Rights (Consolidated Report of the EU, the UN and the World Bank Group, 2015), the quantitative casualties among the civilian population during the entire conflict are 3,052. Given the 298 deaths aboard Malaysia Airlines flight MH17, the figure is 3,350. Estimates of the number of injured are only approximate and, according to the UN, are more than 7,000 people. The total number of victims, including servicemen, is 41-44 thousand, of which 13-13.2 thousand are dead and 29-31 thousand are wounded on both sides of the conflict.

The hostilities led to mass displacement. Accounting for internally displaced persons and providing them.assistance is provided by the Ministry of Social Policy of Ukraine (the Ministry of Internal Affairs of Ukraine, 2014). At the end of 2014, 633,523 internally displaced persons were registered. The following year, the number increased 2.5 times. The peak value reached 1.7 million people and currently (June, 2020) is almost 1.45 million people.

Thus, the key problems that exist in the occupied territories are as follows: 
$>$ declining incomes, poverty;

$>$ deterioration of the demographic situation;

$>$ changes in the economic structure;

$>$ significant economic losses;

$>$ reduction of production volumes in heavy industries;

$>$ damage / loss of infrastructure;

$>$ reduction of trade, including foreign economic relations;

$>$ losses in the social security system, including significant support costs for internally displaced persons;

$>$ loss of public confidence, including through massive propaganda by the Russian Federation in the media.

As a result, military conflicts lead to losses that are not always accurately estimated: human losses, forced displacement, destruction of physical infrastructure, disruption of so-called soft economic infrastructure (for example, existing links between sellers and consumers). As a result, the population loses or has limited access to basic services (water, electricity) and social services. Jobs and production assets are destroyed, and with them sources of income. They experience loss of knowledge and expertise in many areas due to the death of people and their forced relocation. The incidence of the most vulnerable segments of the population is increasing: women, children, youth, and people with disabilities. In conflict-affected regions, the local economy is weakening and the most affected are becoming dependent on humanitarian assistance. Circulation of goods is limited, both due to damage to physical infrastructure and disruptions in supply chains. The purchasing power of citizens is significantly reduced as a result of loss of sources of income. Mass displacement of persons leads to the leaching of skilled labor. Under such conditions, local markets almost cease to operate. Most of the negative effects are interconnected and only reinforce each other (see Fig. 1).

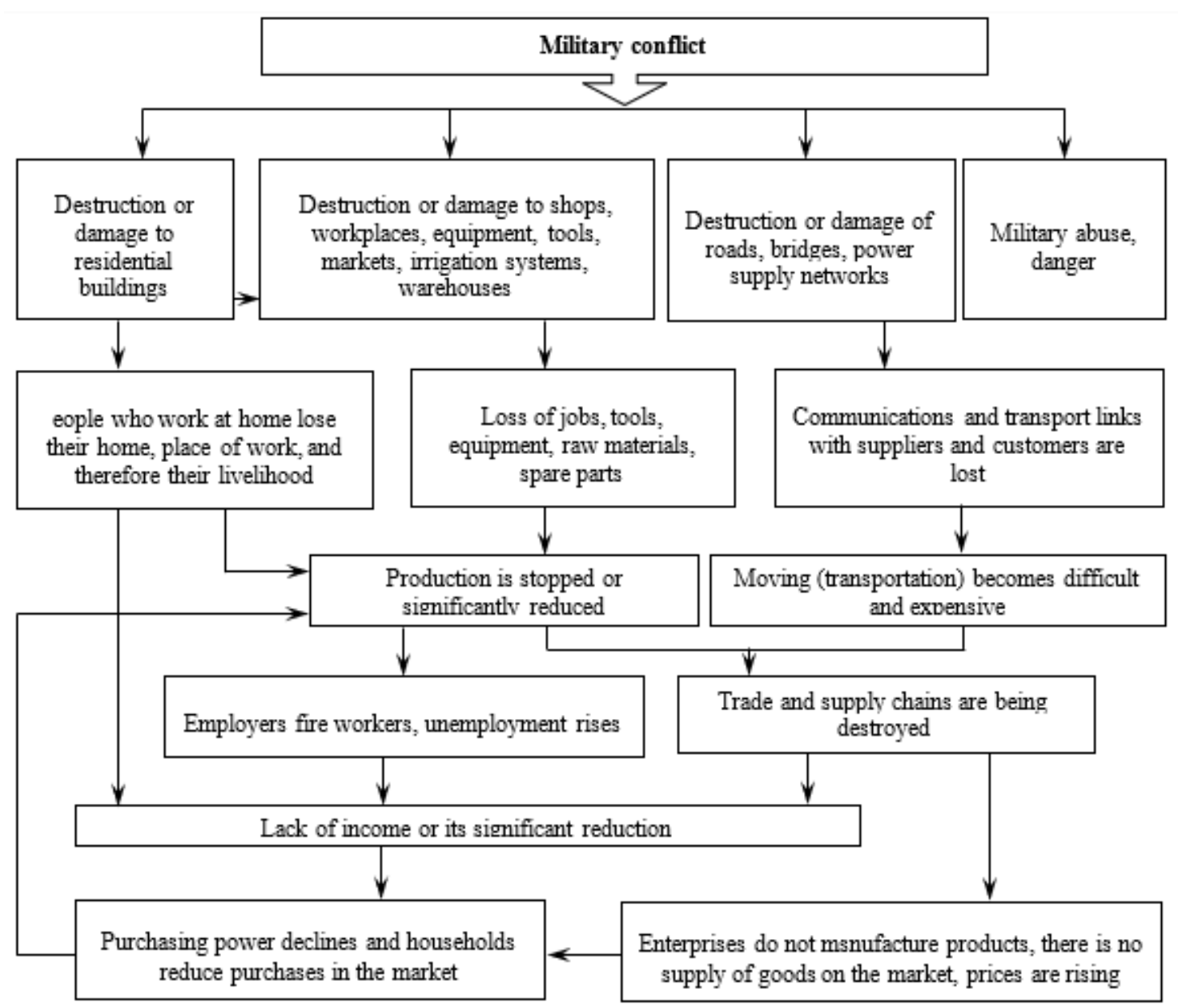

Figure 1. Causal changes in the economy of post-conflict areas

Source: compiled by the authors. 
So we can talk about a wide range of areas for impact investment related to economic recovery in post-conflict regions. In our view, the socio-economic integration of those affected by the conflict is a priority and is based on the ability of the local economy to create new jobs. After years of conflict, the potential of the local economy becomes incapable of self-recovery and therefore needs external assistance in most cases due to declining purchasing power, destruction of economic ties between economic entities, loss of productive assets, inadequate infrastructure, significant risks, instability (and often, lack) of investment flows. In this regard, the funds should be used to reactivate the local economy, mobilize investment resources. Financial support (according to the World Bank, 2019) can be obtained from various sources, including the following:

$>$ budget funding from the government;

$>$ direct budget support from international partners;

$>$ concentration of grant funding through the Trust Fund with many partners;

$>$ international loans;

$>$ support of the financial sector in the form of participation in specialized instruments and guarantees;

$>$ mechanisms to facilitate coordination with private sector investment.

At the same time, in the short term, the assistance is mainly aimed at the gradual elimination of dependence on external sources of funding through the formation of temporary jobs and conditions for income generation. In the long run, internal conditions should be created for the recovery of the local economy and the creation of new permanent jobs.

But any economic recovery begins with the initial stage - peace negotiations. This makes it possible to implement any plans and projects in the conflict. The Ministry of Internal Affairs of Ukraine has formed the Donbass Deoccupation Plan "Small Steps Mechanism", the strategic task of which is to "restore the country's sovereignty and territorial integrity, deoccupation and reintegration of the temporarily occupied territories". The plan includes 11 steps (the Ministry of Internal Affairs of Ukraine, 2014):

1. A separate region (district) of the occupied territories of Donbass is selected and agreed upon, where opposing military formations are diverted beyond the agreed line - a demilitarized security zone is created.

2. The Special International Peacekeeping Mission and the State Border Guard Service of Ukraine shall take control of the specified part of the territory and its borders.

3. Within the limits of the liberated territory, the forces of the bodies of justice of Ukraine shall prepare for the election process and the subsequent holding of local elections in accordance with Ukrainian legislation.

4. The work of all state institutions and law enforcement agencies of Ukraine shall be resumed on the territory of the reintegrated site.

5. The reintegration process begins.

6. The procedure of humanitarian demining of the previously occupied territory is carried out.

7. Immediate work is carried out to eliminate man-made and environmental risks.

8. An urgent program to verify and restore Ukrainian documents is launched for all people who have lived in the occupied territories these years.

9. A program to restore infrastructure and the economy is launched.

10. Work is under way to return internally displaced persons.

11. Participation of citizens living in the formerly occupied territories in elections to the central authorities of Ukraine is restored.

After these steps, the restoration of the occupied territories can be translated into solving socio-economic problems and should include the following stages:

$>$ stabilization, which should cover the target groups of the population that have suffered the greatest losses from the conflict;

$>$ reintegration, which connects the development of local communities;

$>$ transition to sustainable development, which provides for the final integration of the region into the national economy.

Promoting economic development and employment can be achieved through a large number of programs and approaches that differ in their goals, instruments, sectoral focus and timeframe. The type of support should be selected on the basis of a thorough analysis of the local context and its specifics, as there are many examples of negative consequences and lost opportunities arising from insufficient consideration of local characteristics. In 
addition, it is necessary to ensure the compatibility of short-term and long-term benefits that are complementary. In many cases, projects aimed at concrete immediate results (e.g. public works programs) may have the consequences necessary for peace stability. Similarly, projects aimed at long-term goals (for example, stimulating industrial relations) have a significant impact on the realities after the conflict period. It is desirable to start with existing activities, skills, structures and systems, and not to impose ready-made and overly ambitious solutions. In many cases, the application of such an approach will lead to completely different results insufficient to achieve the ambitious goals of sustainable development. This includes maximizing the use of local labor and resources, as well as identifying and strengthening existing or potential cross-sectoral linkages at the local level. Post-conflict recovery is faster with the support of local participants, as it is an incentive for them to achieve long-term economic development results. However, as a rule, these local efforts are not enough to meet the needs and solve all the problems on the ground. Development assistance remains necessary, but it must use, develop and remove barriers for local stakeholders. If development support considers local conditions and specifics, builds and strengthens local capacity in the long run, the project will have a high probability of achieving positive results, which will be maintained with the reduction of external assistance. This involves using and strengthening local skills, manpower and connections to stimulate knowledge and capital accumulation. In 2015, a joint effort of the European Union, the United Nations and the World Bank Group assessed the investment needed to rebuild the affected regions as part of a program to assess ways to restore and build peace in Eastern Ukraine (see Table 4). The assessment itself concerned only the territories controlled by the Government of Ukraine. Losses in the occupied territories are currently not even approximate and require independent on-site analysis. As noted earlier, currently it is impossible to say the prospects for resolving the problem of returning these territories to the control of the Ukrainian authorities. This makes it impossible to specify the areas of impact investment.

Table 4. Estimation of aggregate needs for restoration of government-controlled territories of Eastern Ukraine, mln. USA

\begin{tabular}{|l|c|}
\hline Areas of financial assistance & Sum \\
\hline Infrastructure and social services & $\mathbf{1 2 5 7 , 7}$ \\
\hline Healthcare & 184.2 \\
\hline Education & 9.7 \\
\hline Social assistance & 329.4 \\
\hline Energy & 78.9 \\
\hline Transport & 558.2 \\
\hline Water supply and drainage & 40.1 \\
\hline Environment & 30.0 \\
\hline Public buildings and housing & 27.2 \\
\hline Economic recovery & $\mathbf{1 3 5 , 5}$ \\
\hline Employment & 40.0 \\
\hline Productive forces and means of subsistence & 33.0 \\
\hline Economic planning at the local level & 7.5 \\
\hline SMEs and the private sector & 30.0 \\
\hline Financial services & 25.0 \\
\hline Social sustainability, peacebuilding and public safety & $\mathbf{1 2 6 . 8}$ \\
\hline Understanding vulnerability, risk and social cohesion & 2.5 \\
\hline Promoting social cohesion and building trust & 19.7 \\
\hline Promoting a culture of tolerance through dialogue & 11.4 \\
\hline Protection of the population affected by the conflict & 5.8 \\
\hline Improving access to justice & 8.1 \\
\hline Providing legal assistance & 6.6 \\
\hline Psychosocial support & 28.4 \\
\hline Restoration of public safety & 23.9 \\
\hline Preparation for DDR & 20.4 \\
\hline Total & $\mathbf{1 5 2 0 , 0}$ \\
\hline Sor & \\
\hline
\end{tabular}

Source: compiled by authors.

In general, infrastructure rehabilitation is considered a primary area of investment in post-conflict areas. For example, a study by J. Schwartz and P. Halkyard (Schwartz, Jordan; Halkyard, Pablo, 2006) shows that immediately after the political phase of a peaceful settlement, the post-conflict region / country attracts the attention of international investors who provide the necessary reconstruction assistance to local economy. In the first years, investment volumes are usually significant (up to 20\% of GDP) with a gradual decline after 7-8 years (less than 5\% of GDP). But even at the initial stage (the first year of recovery), most regions have political and 
administrative problems, which limit the opportunities for efficient use of investment. That is why at the initial stage the most important source of assistance is the state budget. The initial period of economic growth and financial assistance is accompanied only by moderate activity of private investors in the field of infrastructure. Significant private investment support materializes only after stability has been maintained in the region for a certain (sometimes long) period. At the same time, moderate investments come almost immediately. Private investment in infrastructure follows a clear sequence of selection of areas of interest, where mobile communications are the primary source of interest immediately after the end of the conflict (see Figure 2). The desire of mobile operators to invest in conditions of ultra-high risk is due to the rapid return on investment. Other areas are not of significant interest in the initial period. Energy projects remain somewhat attractive, especially three years after the conflict, and the frequency of investment increases after five years.

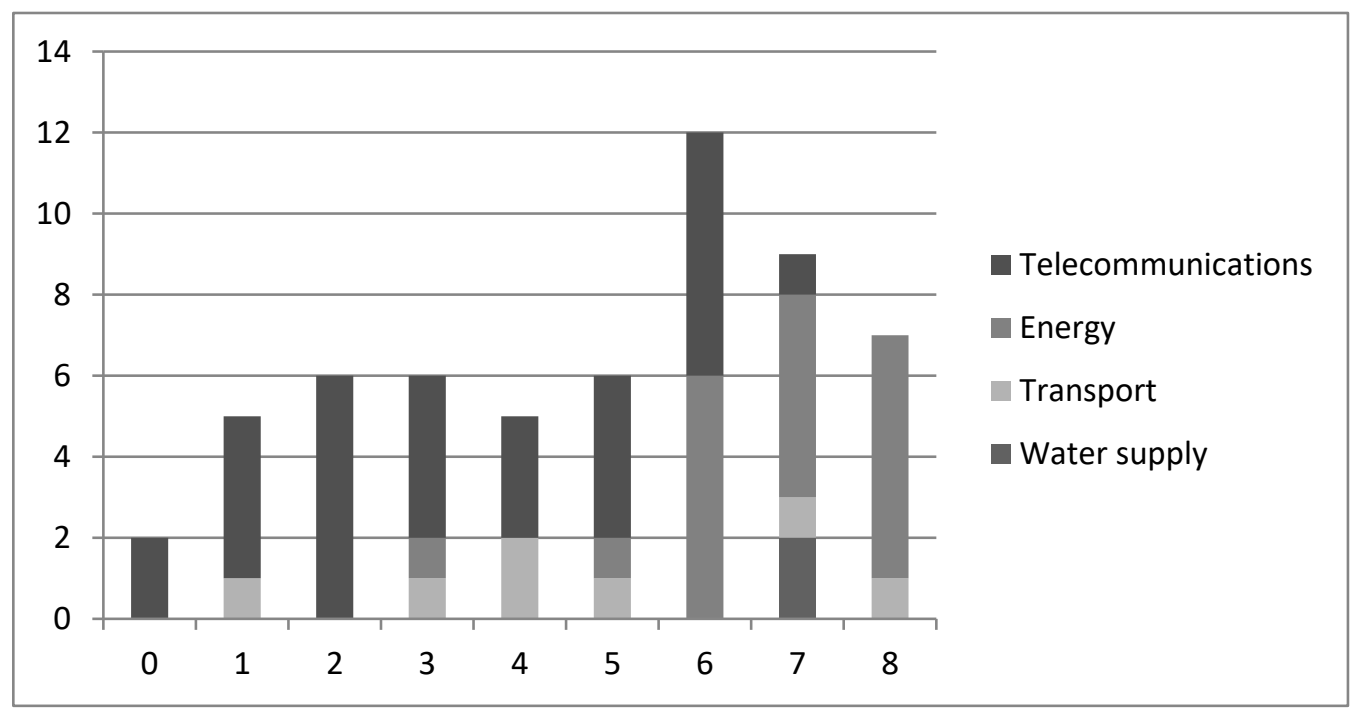

\section{Figure 2. Number of infrastructure investment projects by sector (vertical scale) in post-conflict countries, which were financed by private investment in the years after the achievement of peace (horizontal scale)}

Source: compiled by Schwartz, Jordan; Halkyard, Pablo (2006).

Transport infrastructure mainly attracts private investment in the development of seaports, probably because container terminals offer the opportunity to earn hard currency and because fixed assets can be integrated into vertically integrated logistics systems. Investments in railways, roads and airports usually take place only a few years after the conflict. The water supply sector receives the least investment, although in terms of meeting the basic needs of the population, this area has a high priority.

\section{Conclusions, discussions and recommendations}

Thus, it can be argued that the consequences of the military intervention of the Russian Federation have significantly affected the economic performance of Ukraine. The annexation of the Autonomous Republic of Crimea and the resolution of the conflict in Donetsk and Luhansk oblasts led to a fall in GDP, rising inflation, and unemployment. The economy of Donbass is largely excluded from the general economic space of Ukraine. The data in Table 3 summarize the negative impact of the conflict. Most indicators decreased by 24 times between 2013 and 2019. Thus, we conclude that the focus of impact investments immediately after the political settlement of the conflict in Donbass on infrastructure should be expected only in telecommunications. Other sectors will receive private investment only after a few years of stability, so only public financial support should be considered a key source of funding. That is why, in our opinion, although investments in infrastructure are desirable, but their involvement in the first years of economic recovery in the region seems unpromising.

Funding: self-funded.

Author Contributions: conceptualization, Yulia Yelnikova and Aleksandra Kuzior; data curation, Yulia Yelnikova and Aleksandra Kuzior; formal analysis, Yulia Yelnikova and Aleksandra Kuzior; funding 
acquisition, Yulia Yelnikova and Aleksandra Kuzior; investigation, Yulia Yelnikova and Aleksandra Kuzior; methodology, Yulia Yelnikova and Aleksandra Kuzior; project administration: Yulia Yelnikova and Aleksandra Kuzior; resources, Yulia Yelnikova and Aleksandra Kuzior; software, Yulia Yelnikova and Aleksandra Kuzior; supervision, Yulia Yelnikova and Aleksandra Kuzior; validation, Yulia Yelnikova and Aleksandra Kuzior; visualization, Yulia Yelnikova and Aleksandra Kuzior; writing - original draft, Yulia Yelnikova and Aleksandra Kuzior; writing - review \& editing, Yulia Yelnikova and Aleksandra Kuzior.

\section{References}

1. Bello W. (2006). The Rise of the Relief and Reconstruction Complex. Journal of International Affairs, 59(2), 281-296. Available at: https://ic.ucsc.edu/ rlipsch/pol160A/Bello.pdf.

2. Paul Collier and Anke Hoeffler (2005). Paradigm in Distress? Primary Commodities and Civil War. The Journal of Conflict Resolution, 49(4), 625-633. Available at: https://doi.org/10.1177/0022002705277551.

3. Coning C. (2008). The Coherence Dilemma in Peacebuilding and PostConflict Reconstruction Systems. African Journal on Conflict Resolution, 8(3), 85-110. Available at: https://www.ajol.info/index.php/ajcr/article/view/39432.

4. Murithi T. (2005). Towards a Symbiotic Partnership: The UN Peacebuilding Commission and The Evolving African Union/NEPAD Post Conflict Reconstruction Framework. Available at: https://www.unitar.org/ny/sites/unitar.org.ny/files/BC\%20AU\%20Edited\%20Final\%20Version.pdf.

5. Report on the human rights situation in Ukraine 16 November 2019 to 15 February 2020. https://www.ohchr.org/Documents/Countries/UA/29thReportUkraine EN.pdf.

6. Schwartz, Jordan; Halkyard, Pablo (2006). Post-Conflict Infrastructure: Trends in Aid and Investment Flows. Viewpoint: Public Policy for the Private Sector; Note No. 305. http://documents1.worldbank.org/curated/en/466271468313544274/pdf/356680VP0rev0305Schwartz1 Halkyard.pdf.

7. World Bank (2006). World Bank, Washington, DC. https://openknowledge.worldbank.org/handle/10986/11187.

8. Alexandrova M.M. (2011). Rozvytok systemy strakhuvannya sil's'kohospodars'kykh kul'tur [Development of the crop insurance system]. PhD Thesis, Kyiv, 20 p. Available at: http://www.irbis-nbuv.gov.ua/cgibin/irbis_nbuv/cgiirbis_64.exe?Z21ID=\&I21DBN=REF\&P21DBN=REF\&S21STN=1\&S21REF=10\&S 21FMT $=$ fullwebr $\& \mathrm{C} 21 \mathrm{COM}=\mathrm{S} \& \mathrm{~S} 21 \mathrm{CNR}=20 \& \mathrm{~S} 21 \mathrm{P} 01=0 \& \mathrm{~S} 21 \mathrm{P} 02=0 \& \mathrm{~S} 21 \mathrm{P} 03=\mathrm{A}=\& \mathrm{~S} 21 \mathrm{COLORTE}$ RMS=1\&S21STR=\%D0\%90\%D0\%BB\%D0\%B5\%D0\%BA\%D1\%81\%D0\%B0\%D0\%BD\%D0\%B4\% D1\%80\%D0\%BE\%D0\%B2\%D0\%B0\%20\%D0\%9C\$.

9. Vyhovska N.G. (2010). Rozvytok systemy finansovoho kontrolyu v Ukrayini [Development of the financial control system in Ukraine]. PhD Thesis, Kyiv, 36 p. Available at: http://www.irbis-nbuv.gov.ua/cgibin/irbis nbuv/cgiirbis 64.exe?C21COM=S\&I21DBN=ARD\&P21DBN=\&S21FMT=JwU B\&S21ALL $=\% 28 \% 3 \mathrm{C} . \% 3 \mathrm{EU} \% 3 \mathrm{D} \% \mathrm{D} 0 \% \mathrm{~A} 39 \% 284 \% \mathrm{D} 0 \% \mathrm{~A} 3 \% \mathrm{D} 0 \% \mathrm{BA} \% \mathrm{D} 1 \% 80 \% 29261.8 \$ \% 3 \mathrm{C} . \% 3 \mathrm{E} \% 29 \& \mathrm{Z} 21$

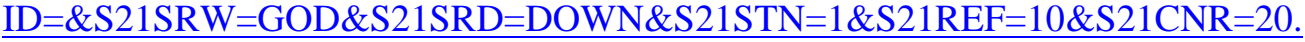

10. Ministerstvo sotsial'noyi polityky. Vnutrishn'o peremishcheni osoby. [Ministry of Social Policy. Internally displaced persons]. Available at: https://www.msp.gov.ua/timeline/Vnutrishno-peremishcheniosobi.html.

11. Drozd I.K. (2006). Systema finansovo-ekonomichnoho kontrolyu v Ukrayini [The system of financial and economic control in Ukraine]. PhD Thesis, Kyiv, 33 p. Available at: http://irbis-nbuv.gov.ua/cgibin/irbis_nbuv/cgiirbis_64.exe?Z21ID=\&I21DBN=EC\&P21DBN=EC\&S21STN=1\&S21REF=10\&S21 FMT $=$ fullwebr $\& C 21 \mathrm{COM}=\mathrm{S} \& S 21 \mathrm{CNR}=20 \& \mathrm{~S} 21 \mathrm{P} 01=0 \& \mathrm{~S} 21 \mathrm{P} 02=0 \& \mathrm{~S} 21 \mathrm{P} 03=\mathrm{A}=\& \mathrm{~S} 21 \mathrm{COLORTER}$ $\mathrm{MS}=1 \& \mathrm{~S} 21 \mathrm{STR}=\% \mathrm{D} 0 \% 94 \% \mathrm{D} 1 \% 80 \% \mathrm{D} 0 \% \mathrm{BE} \% \mathrm{D} 0 \% \mathrm{~B} 7 \% \mathrm{D} 0 \% \mathrm{~B} 4 \% 20 \% \mathrm{D} 0 \% 86 \$$.

12. Yevdokymov V.V. (2011). Kontseptsiya intehrovanoyi systemy bukhhalters'koho obliku: teoriya, metodolohiya, orhanizatsiya [The concept of an integrated accounting system: theory, methodology, organization]. $\mathrm{PhD}$ Thesis, Zhytomyr, 37 p. Available at: http://www.irbis-nbuv.gov.ua/cgibin/irbis nbuv/cgiirbis 64.exe?Z21ID=\&I21DBN=EC\&P21DBN=EC\&S21STN=1\&S21REF=10\&S21 FMT $=$ fullwebr $\&$ C21COM $=S \& S 21 C N R=20 \& S 21 \mathrm{P} 01=0 \& S 21 \mathrm{P} 02=0 \& S 21 \mathrm{P} 03=\mathrm{A}=\& S 21 \mathrm{COLORTER}$ $\mathrm{MS}=1 \& \mathrm{~S} 21 \mathrm{STR}=\% \mathrm{D} 0 \% 84 \% \mathrm{D} 0 \% \mathrm{~B} 2 \% \mathrm{D} 0 \% \mathrm{~B} 4 \% \mathrm{D} 0 \% \mathrm{BE} \% \mathrm{D} 0 \% \mathrm{BA} \% \mathrm{D} 0 \% \mathrm{~B} \%$ D0\%BC\%D0\%BE\%D 0\%B2\%20\%D0\%92\$. 
13. Kindrats'ka L.M. (2002). Systema bukhhalters'koho obliku v komertsiynykh bankakh: metodolohiya ta praktyka [Accounting system in commercial banks: methodology and practice]. $\mathrm{PhD}$ Thesis, Kyiv, $32 \mathrm{p}$. Available at: http://scholar.google.com/scholar?cluster=6250997489287785732\&hl=en\&oi=scholarr.

14. Kondratenko, V., Okopnyk, O., Ziganto, L., \& Kwilinski, A. (2020). Innovation Development of Public Administration: Management and Legislation Features. Marketing and Management of Innovations, 1, 87-94. Available at: https://doi.org/10.21272/mmi.2020.1-06.

15. Kozmenko O.V. (1998). Systema strakhuvannya ekolohichnykh $i$ katastrofichnykh ryzykiv [Environmental and catastrophic insurance]. PhD Thesis, 20 p. Available at: http://www.irbisnbuv.gov.ua/cgibin/irbis_nbuv/cgiirbis_64.exe?Z21ID=\&I21DBN=REF\&P21DBN=REF \&S21STN=1\&S21REF=10\&S 21FMT $=$ fullwebr $\& \mathrm{C} 21 \mathrm{COM}=\mathrm{S} \& \mathrm{~S} 21 \mathrm{CNR}=20 \& \mathrm{~S} 21 \mathrm{P} 01=0 \& \mathrm{~S} 21 \mathrm{P} 02=0 \& \mathrm{~S} 21 \mathrm{P} 03=\mathrm{A}=\& \mathrm{~S} 21 \mathrm{COLORTE}$ RMS=1\&S21STR=\%D0\%9A\%D0\%BE\%D0\%B7\%D1\%8C\%D0\%BC\%D0\%B5\%D0\%BD\%D0\%BA $\% \mathrm{D} 0 \% \mathrm{BE} \% 20 \% \mathrm{D} 0 \% 9 \mathrm{E} \$$.

16. Koldovs'kyi A.V. (2013). Systema valyutnoho rehulyuvannya v konteksti finansovoyi nestabil'nosti ekonomiky [Currency regulation system in the context of financial instability of the economy]. $\mathrm{PhD}$ Thesis, Sumy, 20 p. Available at: http://www.irbis-nbuv.gov.ua/cgibin/irbis nbuv/cgiirbis 64.exe?Z21ID=\&I21DBN=EC\&P21DBN=EC\&S21STN=1\&S21REF=10\&S21 FMT $=$ fullwebr $\& C 21 \mathrm{COM}=S \& S 21 \mathrm{CNR}=20 \& S 21 \mathrm{P} 01=0 \& \mathrm{~S} 21 \mathrm{P} 02=0 \& \mathrm{~S} 21 \mathrm{P} 03=\mathrm{I}=\&$ S21COLORTERM $\mathrm{S}=1 \& \mathrm{~S} 21 \mathrm{STR}=\% \mathrm{D} 0 \%$ A0\%D0\%90398474\$.

17. Kuzior, A., \& Zozulak, J. (2019). Adaptation of the Idea of Phronesis in Contemporary Approach to Innovation. Management Systems in Production Engineering, 27(2), 84-87. Available at: https://doi.org/10.1515/mspe-2019-0014.

18. Kuzior, A., \& Kuzior, P. (2020). The Quadruple Helix Model as a Smart City Design Principle. Virtual Economics, 3(1), 39-57. Available at: https://doi.org/10.34021/ve.2020.03.01(2).

19. Kwilinski, A. (2018). Mechanism of Modernization of Industrial Sphere of Industrial Enterprise in Accordance with Requirements of the Information Economy. Marketing and Management of Innovations, 4, 116-128. Available at: http://doi.org/10.21272/mmi.2018.4-11.

20. Kwilinski, A., \& Kuzior, A. (2020). Cognitive Technologies in the Management and Formation of Directions of the Priority Development of Industrial Enterprises. Management Systems in Production Engineering, 28(2), 133-138. Available at: https://doi.org/10.2478/mspe-2020-0020.

21. Kwilinski, A., Pajak, K., Halachenko, O., Vasylchak, S., Pushak, Ya., \& Kuzior, P. (2019). Marketing Tools for Improving Enterprise Performance in the Context of Social and Economic Security of the State: Innovative Approaches to Assessment. Marketing and Management of Innovations, 4, 172-181. Available at: http://doi.org/10.21272/mmi.2019.4-14.

22. Kwilinski, A., Tkachenko, V., Kuzior, A. (2019). Transparent cognitive technologies to ensure sustainable society development. Journal of Security and Sustainability Issues, 9(2), 561-570. Available at: http://doi.org/10.9770/jssi.2019.9.2(15).

23. Luk'yanenko I.H. (2005). Systemne modelyuvannya mekhanizmu byudzhetnoho rehulyuvannya [System modeling of the mechanism of budgetary regulation]. $\mathrm{PhD}$ Thesis, Kyiv, 34 p. Available at: http://irbisnbuv.gov.ua/cgi-

bin/irbis_nbuv/cgiirbis_64.exe?Z21ID=\&I21DBN=EC\&P21DBN=EC\&S21STN=1\&S21REF=10\&S21 FMT $=$ fullwebr\&C21COM $=S \& S 21 \mathrm{CNR}=20 \& S 21 \mathrm{P} 01=0 \& \mathrm{~S} 21 \mathrm{P} 02=0 \& \mathrm{~S} 21 \mathrm{P} 03=\mathrm{A}=\& \mathrm{~S} 21 \mathrm{COLORTER}$ $\mathrm{MS}=1 \& \mathrm{~S} 21 \mathrm{STR}=\% \mathrm{D} 0 \% 9 \mathrm{~B} \% \mathrm{D} 1 \% 83 \% \mathrm{D} 0 \% \mathrm{BA} \% 27 \% \mathrm{D} 1 \% 8 \mathrm{~F} \% \mathrm{D} 0 \% \mathrm{BD} \% \mathrm{D} 0 \% \mathrm{~B} 5 \% \mathrm{D} 0 \% \mathrm{BD} \% \mathrm{D} 0 \% \mathrm{~B}$ A\%D0\%BE\% 20\%D0\%86\$.

24. Lyashenko, V., \& Pidorycheva, I. (2019). The formation of interstate and cross-border scientificeducational and innovative spaces between Ukraine and the European Union member states in the digital economy. Virtual Economics, 2(2), 48-60. Available at: https://doi.org/10.34021/ve.2019.02.02(3).

25. Matukhno M.O. (2014). Systema administruvannya PDV v Ukrayini: stan ta perspektyvy rozvytku [VAT administration system in Ukraine: state and prospects of development]. Scientific Bulletin of ChDIEU, 3(23), Irpin, pp. 142-146. Available at: http://journals.uran.ua/nvgeci/article/view/38164.

26. Mikhnevych, L., Marchenko, V. Hristov, P., \& Kuzior, A. (2020). Conceptual Relationships Between Country Image and Economic Security. Marketing and Management of Innovations, 1, 285-293. Available at: https://doi.org/10.21272/mmi.2020.1-24.

27. Ministry of Internal Affairs of Ukraine. Donbass deoccupation plan "Small steps mechanism". Available at: https://mvs.gov.ua/ua/pages/4446 Deokupaciya Donbasu.htm/. 
28. Nikitishyn A.O. (2009). Systema opodatkuvannya dokhodiv fizychnykh osib [The system of personal income taxation]. $\mathrm{PhD}$ Thesis, Kyiv, 20 p. Available at: http://194.44.11.130/cgibin/irbis nbuv/cgiirbis 64.exe?C21COM=S\&I21DBN=REF\&P21DBN=REF\&S21FMT=fullwebr \&S21 ALL=\%28\%3C.\%3EA\%3D\%D0\%9D\%D1\%96\%D0\%BA\%D1\%96\%D1\%82\%D1\%96\%D1\%88\%D0 $\% \mathrm{~B} 8 \% \mathrm{D} 0 \% \mathrm{BD} \% 20 \% \mathrm{D} 0 \% 90 \$ \% 3 \mathrm{C} . \% 3 \mathrm{E} \% 29 \& \mathrm{FT}$ REQUEST $=\& \mathrm{FT}$ PREFIX $=\& Z 21 \mathrm{ID}=\& \mathrm{~S} 21 \mathrm{STN}=1$ $\& \mathrm{~S} 21 \mathrm{REF}=10 \& \mathrm{~S} 21 \mathrm{CNR}=20$.

29. Assessment of the restoration and development of peace (2015). Analysis of the impact of the crisis and needs in eastern Ukraine: Consolidated report of the EU, the UN and the World Bank Group. $84 \mathrm{p}$. Available at: http://www.un.org.ua/images/RPA_V1_Ukr.pdf.

30. Pająk, K., Kamińska, B., \& Kvilinskyi, O. (2016). Modern Trends of Financial Sector Development under the Virtual Regionalization Conditions. Financial and Credit Activity: Problems of Theory and Practice, 2(21), 204-217. https://doi.org/10.18371/fcaptp.v2i21.91052.

31. Paslavska R.Yu. (2014). Sutnist' systemy administruvannya podatkiv ta osoblyvosti yiyi funktsionuvannya v Ukrayini [The essence of the tax administration system and features of its functioning in Ukraine], Aktual'ni problemy rozvytku ekonomiky rehionu [Current problems of economic development of the region], issue 9, Lviv, pp. 58-63. Available at: http://irbis-nbuv.gov.ua/cgibin/irbis nbuv/cgiirbis 64.exe?C21COM=2\&I21DBN=UJRN\&P21DBN=UJRN\&IMAGE FILE DO WNLOAD=1\&Image file name=PDF/aprer $2013 \quad 9 \% 281 \% 29 \quad 12 . p d f$.

32. Reznikova O.O. (2001). Systema valyutnoho rehulyuvannya v Ukrayini na suchasnomu etapi [Currency regulation system in Ukraine at the current stage]. $\mathrm{PhD}$ Thesis, Kyiv, $18 \mathrm{p}$. Available at: http://irbisnbuv.gov.ua/cgi-

bin/irbis_nbuv/cgiirbis_64.exe?Z21ID=\&I21DBN=ARD\&P21DBN=ARD\&S21STN=1\&S21REF=10\& S21FMT $=$ fullwebr $\& C 21 \mathrm{COM}=S \& S 21 \mathrm{CNR}=20 \& S 21 \mathrm{P} 01=0 \& \mathrm{~S} 21 \mathrm{P} 02=0 \& \mathrm{~S} 21 \mathrm{P} 03=\mathrm{A}=\& \mathrm{~S} 21 \mathrm{COLORT}$ ERMS $=1 \&$ S21STR=\%D0\%A0\%D0\%B5\%D0\%B7\%D0\%BD\%D1\%96\%D0\%BA\%D0\%BE\%D0\%B2 $\%$ D0\%B0\%20\%D0\%9E.\%D0\%9E.\$.

33. Surmin Yu.P. (2003). Teoriya sistem i sistemnyy analiz: ucheb. posobiye [Systems theory and systems analysis: textbook]. Kyiv: MAUP. 368 p. Available at: http://maup.com.ua/assets/files/lib/book/n571.pdf. 